\title{
Report: central diabetes insipidus and schwannoma in a male with X-linked congenital adrenal hypoplasia
}

\author{
Boo Kyeong Seo 1,2, Seul Ah. Jeong 1,2, Jae Young Cho 1,2, Ji Sook Park ${ }^{1,2}$, Ji-Hyun Seo ${ }^{1,2}$, Eun Sil Park ${ }^{1,2}$, \\ Jae-Young Lim ${ }^{1,2^{*}}$, Hyang-Ok Woo ${ }^{1,2}$ and Hee-Shang Youn ${ }^{1,2}$
}

\begin{abstract}
Background: DAX1 mutations are related to the X-linked form of adrenal hypoplasia congenita (AHC) in infancy and to hypogonadotropic hypogonadism $(\mathrm{HH})$ in puberty. We report a male patient affected by X-linked AHC who presented with central diabetes insipidus and schwannoma in adulthood, which has not been described in association with AHC

Case presentation: A 36-day-old male infant who presented with severe dehydration was admitted to the intensive care unit. His laboratory findings showed hyponatremia, hyperkalemia, hypoglycemia, and metabolic acidosis. After hormonal evaluation, he was diagnosed with adrenal insufficiency, and he recovered after treatment with hydrocortisone and a mineralocorticoid. He continued to take hydrocortisone and the mineralocorticoid after discharge. At the age of 17, he did not show any signs of puberty. On the basis of a GnRH test, a diagnosis of HH was made. At the age of 24 , he was hospitalized with thirst, polydipsia and polyuria. He underwent a water deprivation test for polydipsia and was diagnosed with central diabetes insipidus. By quantitative polymerase chain reaction analysis, we identified a hemizygous frameshift mutation in DAX1 (c.543delA).
\end{abstract}

Conclusions: We suggest that DAX1 mutations affect a wider variety of endocrine organs than previously known, including the posterior pituitary gland.

Keywords: Adrenal hypoplasia congenita, Central diabetes insipidus, Schwannoma

\section{Background}

Adrenal hypoplasia congenita (AHC, OMIM 300200), which is caused by mutation of the dosage-sensitive sex reversal (DSS)-adrenal hypoplasia critical region on chromosome $\mathrm{X}$, gene 1 (DAX1) gene, results in adrenal failure in males. Males with AHC often do not undergo puberty owing to hypogonadotropic hypogonadism $(\mathrm{HH})$ caused by the same mutated $D A X 1$ gene [1].

\footnotetext{
* Correspondence: pedneu@gnu.ac.kr

1 Department of Pediatrics, Gyeongsang National University School of Medicine, 92 Chilam-dong, Jinju, Gyeongnam 660-751, South Korea ${ }^{2}$ Gyeongsang Institute of Health Science, Jinju, Korea
}

The DAX1 protein, also known as human nuclear receptor subfamily 0 , group $\mathrm{B}$, member 1 (NROB1), is encoded by an X-linked gene that acts at multiple levels in the development of the adrenal glands, hypothalamus, pituitary, ovaries, and testes and is expressed in these tissues during development and postnatal life. However, the exact biological role of $D A X 1$ is unknown [1-5]. $\mathrm{HH}$ is thought to be likely due to developmental defects in the hypothalamus and pituitary gland, suggesting a role for $D A X 1$ in the development of these organs.

The objective of this case report is to show, likely for the first time, that $D A X 1$ is a survival signal or is related to maintenance of the posterior pituitary gland. To our

C C The Author(s). 2020 Open Access This article is licensed under a Creative Commons Attribution 4.0 International License, which permits use, sharing, adaptation, distribution and reproduction in any medium or format, as long as you give appropriate credit to the original author(s) and the source, provide a link to the Creative Commons licence, and indicate if changes were made. The images or other third party material in this article are included in the article's Creative Commons licence, unless indicated otherwise in a credit line to the material. If material is not included in the article's Creative Commons licence and your intended use is not permitted by statutory regulation or exceeds the permitted use, you will need to obtain permission directly from the copyright holder. To view a copy of this licence, visit http://creativecommons.org/licenses/by/4.0/ The Creative Commons Public Domain Dedication waiver (http://creativecommons.org/publicdomain/zero/1.0/) applies to the data made available in this article, unless otherwise stated in a credit line to the data. 
knowledge, no such findings have been reported previously in the literature. Our evidence also suggests that in humans, $D A X 1$ plays multiple roles in the development and maintenance of several endocrine organs.

\section{Case presentation}

A 36-day-old male infant was admitted to the intensive care unit (ICU) with severe lethargy, tachypnea, severe dehydration, $12 \%$ weight loss since birth, diarrhea, and fever $\left(38^{\circ} \mathrm{C}\right)$. His prenatal and birth history (term; birth weight, $3500 \mathrm{~g}$ ) were unremarkable, and he exhibited normal male genital development. The biochemical measurements showed hyponatremia $(\mathrm{Na}, 126 \mathrm{mmol} / \mathrm{L})$, normochloremia $(\mathrm{Cl}, 100 \mathrm{mmol} / \mathrm{L})$, hyperkalemia $(\mathrm{K}$, $10.8 \mathrm{mmol} / \mathrm{L}$ ), and hypoglycemia (glucose, $50 \mathrm{mg} / \mathrm{dL}$ ). $\mathrm{He}$ also had metabolic acidosis due to diarrhea. Arterial blood gas analysis showed a $\mathrm{pH}$ of 7.17 , a carbon dioxide partial pressure of $24 \mathrm{mmHg}$ (reference range: 35-45), and a bicarbonate concentration of $8.9 \mathrm{mEq} / \mathrm{L}$ (reference range: 22-26). The low plasma bicarbonate concentration of $8.9 \mathrm{mEq} / \mathrm{L}(15.1 \mathrm{mEq} / \mathrm{L}$ lower than normal levels) was associated with the reduced carbon dioxide partial pressure of approximately $24 \mathrm{mmHg}$. The patient was given $20 \mathrm{cc} / \mathrm{kg}$ of fluid with $5 \%$ dextrose, sodium chloride, and sodium bicarbonate for $1 \mathrm{~h}$ followed by maintenance fluid. Antibiotics (cefotaxime and gentamicin) were administered after a diagnosis of sepsis. After the initial interventions, his general condition seemed to be recovered, although hyponatremia and hyperkalemia persisted $(\mathrm{Na}, 128 \mathrm{mmol} / \mathrm{L} ; \mathrm{K}, 6.7 \mathrm{mmol} / \mathrm{L})$. Further biochemical investigation showed an extremely high adrenocorticotropic hormone $(\mathrm{ACTH})$ level $(2000 \mathrm{pg} / \mathrm{mL}$; reference range: $0-10.12 \mathrm{pmol} / \mathrm{mL}$ ), high plasma renin activity $(16.8 \mu \mathrm{g} / \mathrm{mL} / \mathrm{hr}$; reference range: $0.32-1.84 \mu \mathrm{g} /$ $\mathrm{mL} / \mathrm{hr})$ and a low aldosterone level $(0.69 \mathrm{ng} / \mathrm{dL}$; reference range: $2.0-110.0 \mathrm{ng} / \mathrm{dL})$. He seemed to exhibit clinical decompensation after being in a highly fragile condition. A stressor (in the case, the infection) seemed to trigger an adrenal crisis.

The patient's karyotype was 46,XY. His 17hydroxyprogesterone level $(0.83 \mathrm{ng} / \mathrm{mL}$; reference range: $0.7-2.5 \mathrm{ng} / \mathrm{mL})$ and testosterone level $(0.95 \mathrm{ng} / \mathrm{mL}$; reference range: $<1.77 \mathrm{ng} / \mathrm{ml}$ ) were normal, so we excluded congenital adrenal hyperplasia. The child was diagnosed with adrenal insufficiency and administered $6 \mathrm{mg}$ of hydrocortisone and $0.1 \mathrm{mg}$ of fludrocortisone (Florinef) once daily. His electrolyte imbalance and hypoglycemia were also corrected (arterial blood gas analysis: $\mathrm{pH}$ 7.34, $\mathrm{PCO}_{2} 37 \mathrm{mmHg}, \mathrm{HCO}_{3} 20 \mathrm{mmol} / \mathrm{L} ; \mathrm{Na}, 137 \mathrm{mmol} / \mathrm{L} ; \mathrm{K}$, $5.7 \mathrm{mmol} / \mathrm{L}$; glucose, $90 \mathrm{mg} / \mathrm{dL}$ ).

The patient was required to maintain glucocorticoid and mineralocorticoid treatment after discharge. We informed the patient's parents that the glucocorticoid should be administered at an increased dose during stressful situations such as surgery, inflammation and trauma. Because his parents' medication compliance was low, the patient was frequently hospitalized for adrenal crisis.

At the age of 17 years, the patient showed no signs of puberty and had no axillary or pubic hair (Tanner stage 1). His basal gonadotropin levels were measured; the LH level was $0.40 \mathrm{mIU} / \mathrm{mL}$, and the FSH level was $3.26 \mathrm{mIU} / \mathrm{mL}$. A $\mathrm{GnRH}$ test (Relefact, $0.1 \mathrm{mg}$, Aventis Pharma, gonadorelin acetate) was performed, which showed prepubertal gonadotropin peak levels (LH $1.07 \mathrm{mU} / \mathrm{mL}, \mathrm{FSH}, 3.58 \mathrm{mU} /$ $\mathrm{mL})$. These results, together with the lack of any sign of puberty, were consistent with the diagnosis of $\mathrm{HH}$. The patient was given testosterone replacement therapy, which induced clinical signs of puberty, including a growth spurt. Other hormone levels were also tested. The results of the thyroid function test were in the normal ranges (T3 11.40 $\mathrm{ng} / \mathrm{dL}$, TSH $0.72 \mathrm{mIU} / \mathrm{L}$, free T4 $1.27 \mathrm{ng} / \mathrm{dL}$ ). The growth hormone axis test results were also within normal ranges (insulin-like growth factor $1159.0 \mathrm{ng} / \mathrm{mL}$;reference range: $57-426 \mathrm{ng} / \mathrm{mL}$, basal growth hormone $0.26 \mathrm{ng} / \mathrm{mL}$; reference range: $0.18-9.76 \mathrm{ng} / \mathrm{mL}$ ). Abdominal computed tomography conducted at the time $\mathrm{HH}$ was diagnosed revealed severe atrophy of both adrenal glands (Fig. 1).

At the age of 24, the patient's height was $180 \mathrm{~cm}$ (in approximately the 75th centile). He continued to have very low levels of arginine vasopressin (AVP, $1.47 \mathrm{pg} /$ $\mathrm{mL})$ and exhibited hypernatremia $(146.1 \mathrm{mmol} / \mathrm{L})$ and persistent strong thirst. He presented with polydipsia and polyuria $(7 \mathrm{~L} /$ day), and his urinalysis showed low specific gravity (1.002) and low urine osmolarity (54 $\mathrm{mOsm} / \mathrm{kg} \mathrm{H}_{2} \mathrm{O}$ ). Because his serum glucose and HbA1c levels were in the normal range, we ruled out diabetes mellitus. He underwent a water deprivation test, and the results revealed that the urine was not concentrated based on osmolality and that the urine output and serum sodium level were not changed, thus excluding primary polydipsia (Fig. 2a). We then conducted a vasopressin challenge test to check for central diabetes insipidus and found that the patient's urine was five times more concentrated than normal according to osmolality. Subsequently, the patient was diagnosed with central diabetes insipidus (Fig. 2b). Magnetic resonance imaging showed a loss of signal in the posterior pituitary gland and an abnormal mass in the maxillary sinus (Fig. 3). The signal changes in the posterior pituitary gland were consistent with central diabetes insipidus. After diagnosis, the symptoms were controlled with desmopressin spray $(15 \mu \mathrm{g}$ per dose twice a day). Because there has been no change in size, the left maxillary sinus mass is presumed to be a schwannoma and is being observed every 6 months without excision. We shared the diagnosis and treatment plan with the patient.

An outside laboratory then conducted quantitative polymerase chain reaction (PCR) analysis to identify 


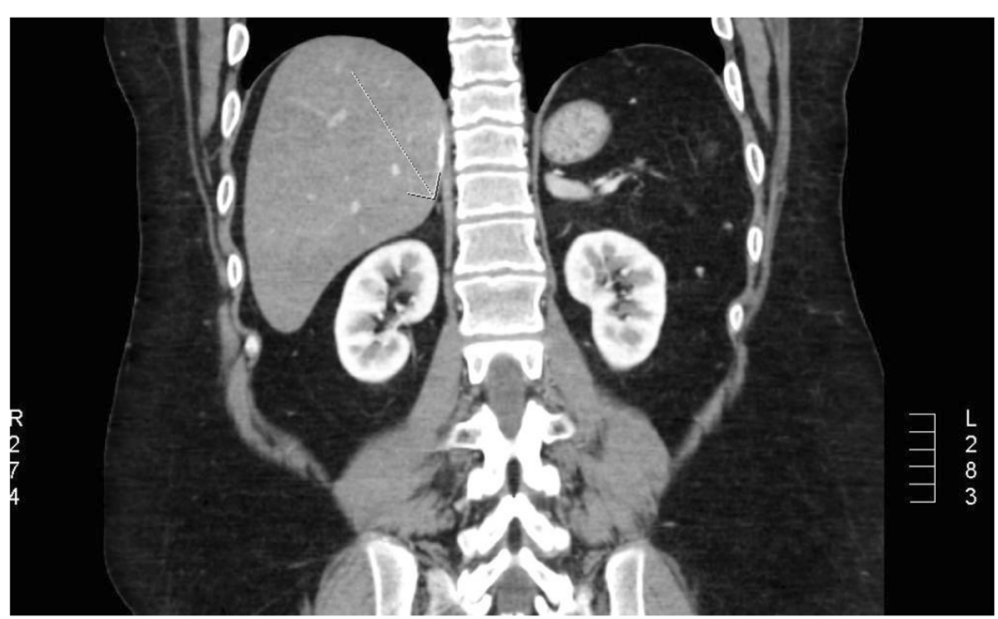

Fig. 1 Abdominal CT scan results showing severely atrophied adrenal glands (arrow)

mutations in $D A X 1$. PCR revealed that a base located at position 543 on gene $D A X 1$, the causative gene of AHC, was deleted, which caused the 183rd amino acid, glycine, to be replaced with valine. This mutation was a frameshift mutation resulting in replacement of the 81st amino acid codon with a stop codon, which induced a loss of function (Fig. 4). The initial sequencing results (at 17 years old) were misread, but our hospital's molecular diagnostic team found the errors when they reread the PCR sequencing results.

In summary, this male exhibited no genital abnormality at birth and was determined to be 46,XY with adrenal insufficiency, $\mathrm{HH}$ and central diabetes insipidus, consistent with the diagnosis of $\mathrm{AHC}$, despite the unusual presence of diabetes insipidus. For maintenance, he was prescribed hydrocortisone, a mineralocorticoid and vasopressin.

\section{Discussion and conclusions}

This is the first report of central diabetes insipidus in adulthood in an AHC patient, suggesting that the DAX1 gene in $\mathrm{AHC}$ affects more endocrine organs than previously believed.

Three patients with a hemizygous frame shift mutation in DAX1 (c.543delA) have been described in the literature pertaining to AHC. In addition, we are aware of another AHC patient with the same mutation as our patient [6]. That patient was delivered at 38 weeks of gestational age with a birth weight of $3160 \mathrm{~g}$. He was admitted to the
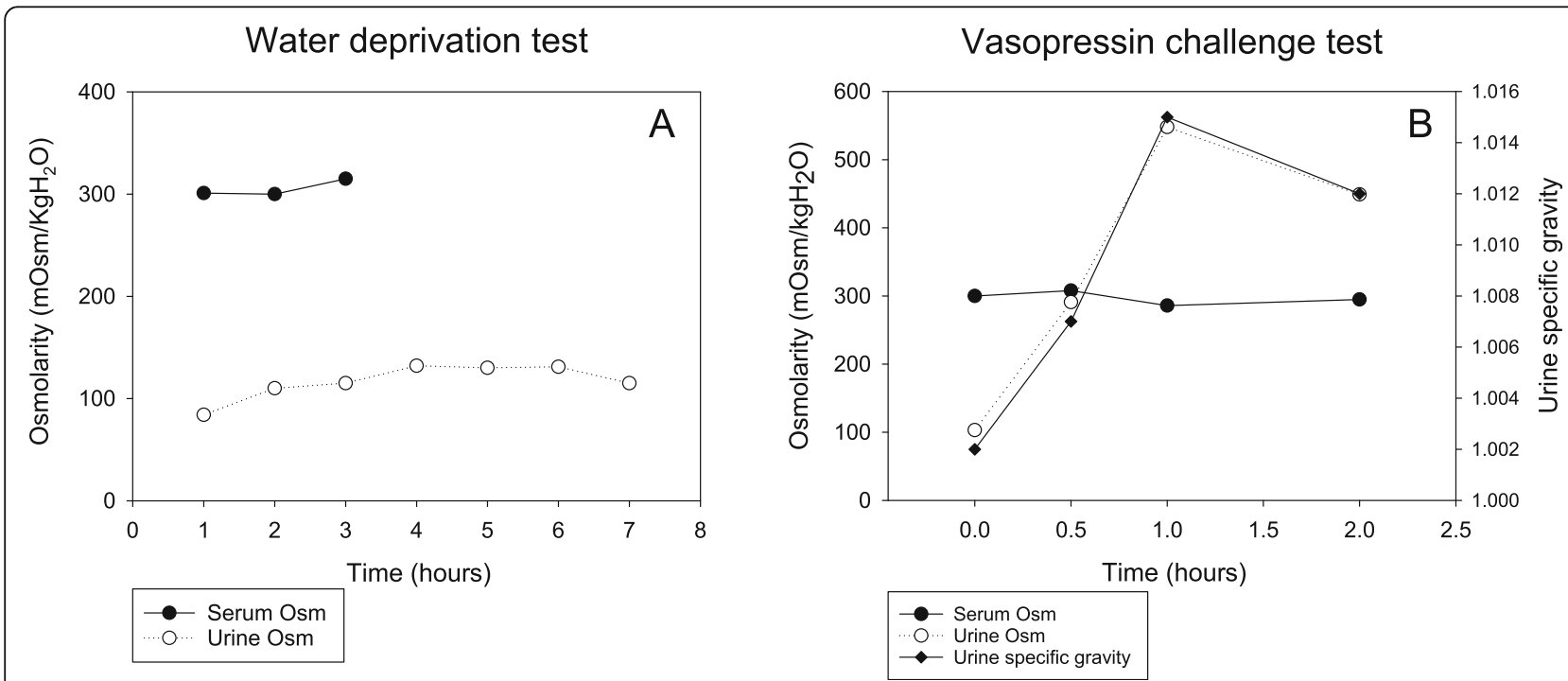

Fig. 2 Water deprivation test results (a). Vasopressin challenge test results (b). There was no change in urine osmolality during the water deprivation test, while a greater than fivefold increase in urine osmolality was observed after administration of vasopressin 

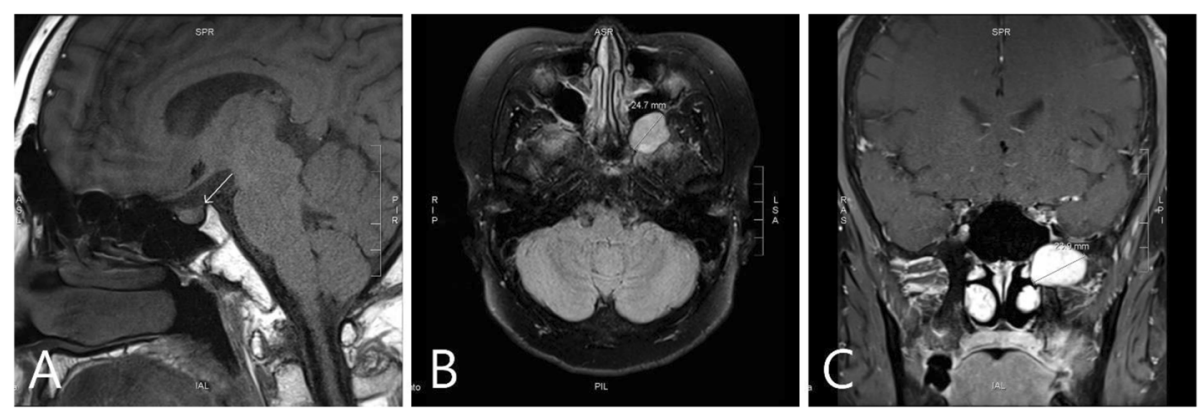

Fig. 3 Magnetic resonance image of the sella turcica. Sagittal T1W1 (a). Axial T2W1 (b). Coronary enhanced T1W1 (c). Loss of normal T1 hyperintensity was observed in the posterior lobe of the pituitary gland (arrow). An enhanced $2.5-\mathrm{cm}$ mass suspected of being a schwannoma is visible in the area of the left pterygopalatine fossa

neonatal ICU at birth because of neonatal respiratory distress syndrome. After exogenous pulmonary surfactant replacement, he recovered and was discharged. However, 7 days after discharge (on postnatal day 18), he returned to the hospital because of poor weight gain and severe dehydration. Laboratory results revealed primary adrenal insufficiency, and he was diagnosed with AHC due to the same mutation (c.543delA) of the $D A X 1$ gene that was found in our patient. That child is now 12 years old. His younger brother has the same mutation in $D A X 1$ but has not yet shown symptoms of central diabetes insipidus.

$D A X 1$ is expressed in tissues and cells involved in steroid hormone production and reproductive function, including the adrenal cortex, testicular Leydig and Sertoli cells, ovarian theca and granulosa cells, pituitary gonadotropes, the ventromedial hypothalamic nucleus in the brain and some other brain areas (arcuate nuclei, amygdala, hippocampus, cerebral cortex) $[3,4,7,8]$.

AVP is synthesized in the hypothalamus. Specifically, it is principally produced by neurons whose cell bodies are within the supraoptic nuclei of the hypothalamus. It is also produced, albeit in smaller quantities, in neurons with cell bodies located in the paraventricular nuclei, the primary sites of production of oxytocin, a homologous hormone primarily involved in uterine contraction and milk letdown. Storage vesicles are transported down neuronal axons through the hypothalamic-hypophysial tract and are ultimately released in the posterior pituitary gland $[9,10]$.

However, the mechanisms of DAX1 action in the hypothalamus and pituitary gland during development and adult function remain unknown. More studies are

\section{GJM Sanger sequencing result \\ NM_000475.4(NR0B1): c.543del, p.Gly183ValfsTer81}
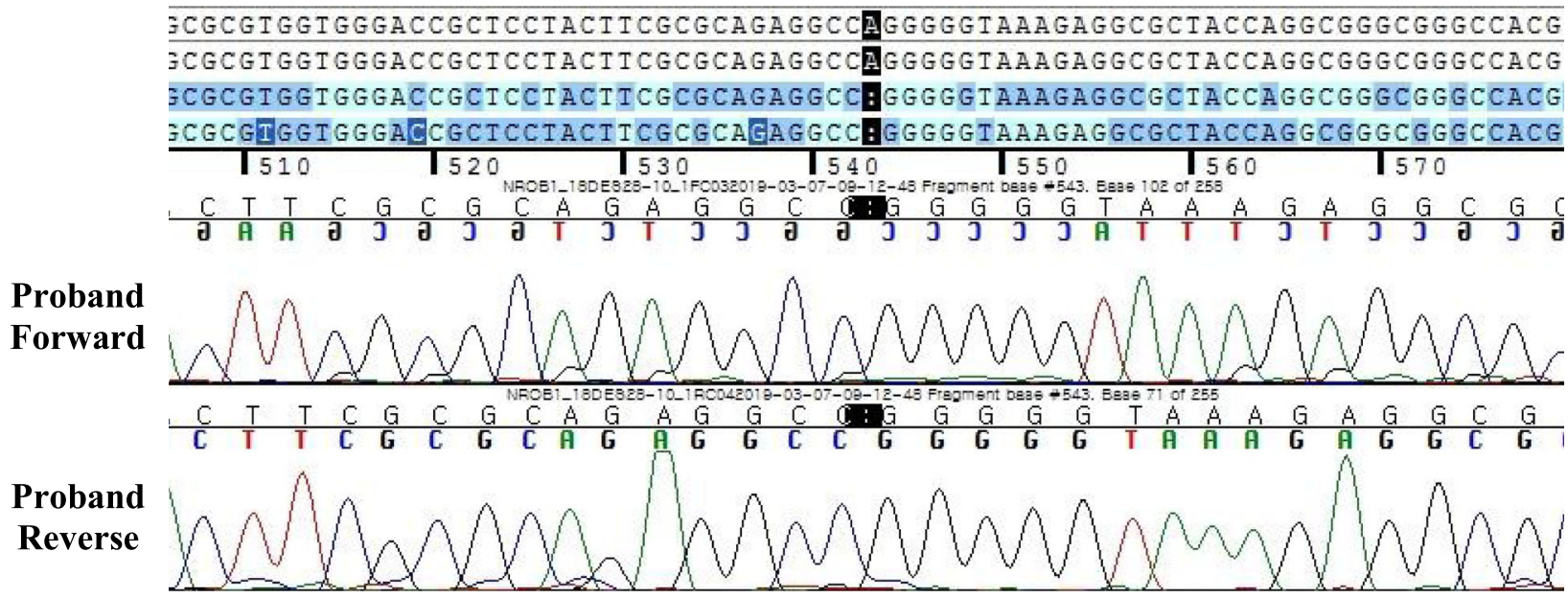

Fig. 4 Identification of a hemizygous missense mutation in the DAX1 gene located at Xq21. The sequencing chromatogram shows a point mutation of c.543del. This mutation leads to the replacement of glycine with valine at the 183rd residue, triggering early termination 
needed to determine the exact roles of $D A X 1$ in the hypothalamus and pituitary gland.

Two cases of DAX1 mutations have been reported in association with hypothalamic and pituitary defects in gonadotropin production [11].

$D A X 1$ may play pleiotropic roles during the development and adult functioning of the hypothalamic-pituitaryadrenal-gonadal axis. If so, $D A X 1$ mutations could cause various complex endocrine phenotype defects $[2,11]$.

There have also been reports that DAX1 expression is related to cancer. As we have previously observed in an animal study, $D A X 1$ is expressed in various brain tissues [12-15]. Notably, our patient's younger sister was diagnosed with pontine glioma at the age of 5 years. We believe that her brother's schwannoma may be related to $D A X 1$ mutation and to cancer originating from brain tissues. In AHC patients, DAX1 is mutated at the germline level. Thus, more studies are needed to determine cancer prevalence and type among these patients.

It is also possible that $D A X 1$ functions as a repressor that controls the rate of stem cell differentiation during organ development [16]. Premature differentiation of pluripotent stem cells into mature cells without prior expansion of cell numbers could lead to transient overactivity and then to subsequent organ hypoplasia due to depletion of the pluripotent cell pool. A clinical case in which the axis was active from the infantile period to the age of 3 years supports this hypothesis [17]. Additional evidence for this hypothesis comes from a mouse model of DAX1 exon 2 deletion [18]. This mouse model has been used to show that during the aging process, $D A X 1$-deficient mice experience adrenal failure. However, it is possible that the numbers of stem cells could differ among species and endocrine tissues.

In conclusion, as the life expectancy of AHC patients increases with the development of improved treatment strategies, we expect more cases to be identified. We think our patient is the first example of such a case.

\section{Abbreviations}

AHC: Adrenal hypoplasia congenita; $\mathrm{HH}$ : Hypogonadotropic hypogonadism; NROB1: Nuclear receptor subfamily 0, group B, member 1; DAX1: Dosagesensitive sex reversal-adrenal hypoplasia critical region on chromosome $\mathrm{X}$, gene 1; SF1: Steroidogenic factor 1

\section{Acknowledgments}

This report received no specific grant from any funding source.

\section{Authors' contributions}

Study conception and design: LJ. Acquisition of data: JS, CJ. Analysis and interpretation of data: PJ, SJ, PE. Drafting of manuscript: SB. Critical revision: $\mathrm{WH}, \mathrm{YH}$. This manuscript has been read and approved by all authors.

\section{Funding}

None.

Availability of data and materials

Not applicable.

\section{Ethics approval and consent to participate}

This case report was written based on the participant's medical record without the performance of new procedures or the administration of new medications. It complies with the content of the Declaration of Helsinki. In addition, the patient signed a "Donation Agreement for Human Derivatives," which covers patient epidemiological and clinical information and human derivatives (referring to human body products and genetic information) that can be used for research. The participant is currently 24 years old (an adult) and has agreed to the publication of this report.

\section{Consent for publication}

The participant was informed of this manuscript and has provided written consent for publication of this report. Written informed consent for the publication of his clinical details and/or clinical images was also obtained from the patient.

\section{Competing interests}

The authors declare that they have no competing interests.

Received: 3 September 2019 Accepted: 18 May 2020

Published online: 27 May 2020

\section{References}

1. Guo W, Burris TP, McCabe ERB. Expression of DAX-1, the gene responsible for X-linked adrenal hypoplasia congenita and hypogonadotropic hypogonadism, in the hypothalamic-pituitary-adrenal/gonadal axis. Biochem Mol Med. 1995;56(1):8-13.

2. Stickels R, Clark K, Heider TN, Mattiske DM, Renfree MB, Pask AJ. DAX1/ NROB1 was expressed during mammalian gonadal development and gametogenesis before it was recruited to the eutherian $\mathrm{X}$ chromosome. Biol Reprod. 2015;92(1):22.

3. Iyer AK, McCabe ER. Molecular mechanisms of DAX1 action. Mol Genet Metab. 2004:83(1-2):60-73.

4. Ikeda Y, Swain A, Weber TJ, Hentges KE, Zanaria E, Lalli E, Tamai KT, SassoneCorsi P, Lovell-Badge R, Camerino G, Parker KL. Steroidogenic factor 1 and Dax-1 colocalize in multiple cell lineages: potential links in endocrine development. Mol Endocrinol. 1996;10(10):1261-72.

5. Ikeda Y, Takeda Y, Shikayama T, Mukai T, Hisano S, Morohashi Kl. Comparative localization of Dax1 and Ad4BP/SF1 during development of the hypothalamic-pituitary-gonadal axis suggests their closely related and distinct functions. Dev Dyn. 2001;220(4):363-76.

6. Park SH, Hong YH, Kim SS. Primary adrenal insufficiency in a newborn with adrenal hypoplasia congenita caused by a mutation of the DAX1 gene. Neonatal Med. 2016;23(1):53-8.

7. Swain A, Zanaria E, Hacker A, Lovell-Badge R, Camerino G. Mouse Dax1 expression is consistent with a role in sex determination as well as in adrenal and hypothalamus function. Nat Genet. 1996;12(4):404-9.

8. Tamai KT, Monaco L, Alastalo TP, Lalli E, Parvinen M, Sassone-Corsi P. Hormonal and developmental regulation of DAX1 expression in Sertoli cells. Mol Endocrinol. 1996;10(12):1561-9.

9. Cuzzo B, Lappin SL. Vasopressin (antidiuretic hormone, ADH). StatPearls (Internet). 2019. http://www.ncbi.nlm.nih.gov/books/NBK526069/.

10. Boron W, Boulpaep E. Medical physiology. 2nd ed. Philadelphia: Saunders Elsevier; 2009. p. 1016-7

11. Habiby RL, Boepple P, Nachtigall L, Sluss PM, Crowley WF Jr, Jameson JL. Adrenal hypoplasia congenita with hypogonadotropic hypogonadism. Evidence that DAX-1 mutations lead to combined hypothalamic and pituitary defects in gonadotropin production. J Clin Invest. 1996:98(4):1055-62.

12. Oda T, Tian T, Inoue M, Ikeda J, Qiu Y, Okumura M, Aozasa K, Morii E. Tumorigenic role of orphan nuclear receptor NROB1 in lung adenocarcinoma. Am J Pathol. 2009;175(13):1235-45.

13. Garcia-Aragoncillo E, Carrillo J, Lalli E, et al. DAX1, a direct target of EWS/ FLI1 oncoprotein, is a principal regulator of cell-cycle progression in Ewing's tumor cells. Oncogene. 2008;27(46):6034-43.

14. Kinsey M, Smith R, lyer AK, McCabe ER, Lessnick SL. EWS/FLI and its downstream target NROB1 interact directly to modulate transcription and oncogenesis in Ewing's sarcoma. Cancer Res. 2009:69(23):9047-55.

15. Wu D, Cheung A, Wang Y, Yu S, Chan FL. The emerging roles of orphan nuclear receptors in prostate cancer. Biochim Biophys Acta. 2016;1866(1):22-36 
16. Lalli E, Sassone-Corsi P. DAX-1, an unusual orphan receptor at the crossroads of steroidogenic function and sexual differentiation. Mol Endocrinol. 2003;17(8):1445-53.

17. Takahashi I, Takahashi T, Shoji Y, Takada G. Prolonged activation of the hypothalamus-pituitary-gonadal axis in a child with X-linked adrenal hypoplasia congenita. Clin Endocrinol. 2000;53(1):127-9.

18. Scheys $\mathrm{JO}$, Heaton $\mathrm{JH}$, Hammer GD. Evidence of adrenal failure in aging Dax1-deficient mice. Endocrinology. 2011;152(9):3430-9.

\section{Publisher's Note}

Springer Nature remains neutral with regard to jurisdictional claims in published maps and institutional affiliations.

Ready to submit your research? Choose BMC and benefit from:

- fast, convenient online submission

- thorough peer review by experienced researchers in your field

- rapid publication on acceptance

- support for research data, including large and complex data types

- gold Open Access which fosters wider collaboration and increased citations

- maximum visibility for your research: over $100 \mathrm{M}$ website views per year

At BMC, research is always in progress.

Learn more biomedcentral.com/submissions 